\title{
Soil Pests of Groundnut in West Africa-Species Diversity, Damage and Estimation of Yield Losses
}

\author{
V. C. UMeH ${ }^{1}$, F. WALIYAR ${ }^{1}$, S. TraorÉ ${ }^{2}$ AND E. EgWURUbE ${ }^{3}$ \\ ${ }^{1}$ International Crops Research Institute for the Semi-Arıd Tropıcs (ICRISAT) \\ B.P. 320 Bamako, Mall; \\ 2Institut d'Etudes et de Recherches Agricoles (INERA) \\ 01 B.P. 910 Bobo-Dioulasso, Burkina-Faso; \\ ${ }^{3}$ Institute of Agricultural Research (IAR), Ahmadu Bello University \\ PMB 1044, Zaria, Nigeria
}

(Accepted 28 June 1999)

\begin{abstract}
Among the major arthropods in soil and plant samples taken from groundnut farms durıng the 1996 cropping season in Malı, Burkına-Faso, Niger, and Nigerıa, termites in the genus Microtermes (Isoptera: Termitidae) were the most abundant and widely distributed species of economicimportance. None of the termite species identified on trees in the surveyed farms attacked groundnuts. At plant maturity, termites were less frequently observed in soils taken from bare ground but were predominantly found on plants. Residues of previous cereal crops in the fields contributed to termite spread. Most of the whitegrub (Coleoptera: Scarabaeidae) and millipede (Myriapoda: Odontopygidae) species identified belonged to the genera of Schyzonycha and Peridontopyge respectively. There was a general decrease in both their population densities and the percentages of farms they infested at plant maturity compared to the early stages of the crop. Mean percentages of plants attacked by termites, whitegrubs and millipedes in the surveyed groundnut fields were 39.4, 10.9 , and $9.3 \%$ respectively. Yield loss due to termites, which predominantly damaged harvested kernels, was estimated at 9.6-30.4\%, and was significantly correlated with percentage of plants damaged by termites $\left(r^{2}=073\right)$.
\end{abstract}

Key Words: Arachrs hypogaea, groundnut soll pests, termites, West Africa

Résumé-Les échantıllons de sols et de plantes pris dans les champs d'arachidependant la campagne de 1996 au Mall, Burkina-Faso, Niger et Nigeria ont montré que parmı les groupes d'arthropodes nuisıbles du sol d'ımportance économıque, des espèces de termites Microtermes étaient les plus abondantes et largement distribuées. Aucune des espèces de termites identifiées sur les arbres échantillonnés n'avaient attaqué les arachides. Pendant la maturation des plantes, les termites ont été fréquemment moins observés dans les échantillons du sol prélevés, mais ıls prédominarent dans les échantillons de plantes. Les résıdus des cultures de céréales ont contıbué à la propagation des termites. La plupart des espèces de vers blancs (Coléoptère: Scarabaeidae) et de mille-pattes (Myriapode: Odontopygidae) identifiées font partie des genres Schyzonycha et Peridontopyge, respectivement. Ily avait généralement une bässe-des populations-de-ces espèces de vers blancs et mille-pattes, et le pourcentage de champs infestés pendant la maturité des plantes par rapport à 2545 jours après les semis. Les pourcentages moyens de plantes attaquées par les termites, les vers blancs et les mille-pattes étaient de 39,4,10,9, et 9,3\% respectivement. Les pertes de rendements occasionnées aux gousses par les termites qui sont principalement responsables des dégâts sur les graines sont estımées à 9,6-30,4\%, sont significatıvement corrélées au pourcentage de plantes endommagées par les termites $\left(r^{2}=0,73\right)$. 


\section{INTRODUCTION}

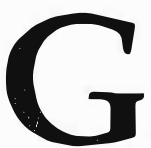
roundnut, Arachis hypogaea L., is a major cash crop and a source of protein for many households in the semi-arid tropics of West and Central Africa (WCA). Unfortunately, its premier position as one of the major export commodities in the sub-region has been reduced by unstable agricultural policies, drought, pests, diseases, and improper application of some cultural practices by farmers (Dicko and Lynch, 1995).

The economic importance of soil pests such as termites, whitegrubs (Coleoptera: Scarabaeidae) and millipedes (Myriapoda: Odontopygidae) in groundnut production is well documented (Johnson et al., 1981; Masses, 1981; Lynch et al., 1986). The additive effect of damage by soil pests to that due to diseases can result in significant yield loss of groundnuts. Under uncontrolled conditions, yield losses of up to $40 \%$ due to termite damage alone have been recorded (Johnson et al., 1981).

The most important group of termites associated with groundnuts are fungus growers of the sub-family Macrotermitinae, notably Microtermes and Odontotermes species. Whitegrubs damage groundnut roots and pods, thereby lowering the quality and quantity of harvested kernels (Wightman and Wightman, 1994). Millipedes usually damage germinating plants or soft developing pods, causing severe stand losses in some parts of WCA, especially at the early stage of groundnut growth. Masses (1981) reported a , $20 \%$ reduction in plant density and $30-40 \%$ reduction in yields due to millipede damage in Senegal. Damage by soil pests was found to be associated with infection by various fungus species including Aspergillus spp. noted for the production of carcinogenic aflatoxins (Mercer, 1978; Johnson and Gumel, 1981; Waliyar et al., 1994 ; Wightman and Wightman, 1994).

Previous studies on soil pests of groundnut in West Africa centred on specific pest groups, and were concerned with individual countries. The present study cuts across the greater portion of the West African groundnut belt, and seeks to identify the major soil pests of groundnuts, their relative importance, factors affecting their abundance, level of damage and yield losses in the sub-region. The information thus obtained will be used in planning effective soil pest control measures for the sub-region. Surveys of 70 groundnut farms were undertaken in the 1996 cropping season along the groundnut belts of Mali, Burkina-Faso, Niger, and Nigeria (Fig. 1) which lie between latitudes $10^{\circ}$ and $13^{\circ} 30^{\prime}$, with annual rainfall of 600-1100 $\mathrm{mm}$.

\section{Materials and Methods}

\section{Soil and plant sampling}

In each selected area, the 70 smallholder groundnut farms were sampled (at least $2 \mathrm{~km}$ apart) 25-45 days after planting (DAP) from late June to early August 1996, and again at maturity from late September to early November to assess yield losses.

In each of the small (less than $2500 \mathrm{~m}^{2}$ area) farms, 40 core soil samples of $7 \mathrm{~cm}$ diameter and $30 \mathrm{~cm}$ depth were taken with an Edelman auger, while in farms $2500 \mathrm{~m}^{2}$ or bigger, 60 were taken. To isolate soil pests, the soil samples were passed through a $40 \times 40 \mathrm{~cm}$ locally made sieve of $1.5 \mathrm{~mm}$ mesh into a plastic container, then the sieved soil sorted manually for any remaining soil arthropods which may have passed through the mesh. All retrieved soil pests were then counted and representative samples were stored in $70 \%$ alcohol for further identification in the laboratory. Core soil samples taken from each field were mixed and a representative sample taken from the mixture to analyse for sand, silt, clay, and organic matter content, and $\mathrm{pH}$ level. The soils were classsified using the textural triangle of Brady (1984).

Termite mounds, where present, were opened using a cutlass or hoe and termites species within them were identified. Observation on damage by soil pests was made on a plant close to where each soil sample was taken. Therefore, the same number of soil and plant samples were taken in each farm. Damaged plants were uprooted in order to observe the extent of damage and its possible causes. Yield losses were estimated by using the methods of Johnson et al. (1981).

Effects of arboreal termites, levels of plant residues, weeds, and annual rainfall on damage to groundnuts

Termite species found on the trees present in sampled farms were identified and compared with those damaging groundnuts in order to establish if there was any relationship between them. The levels of plant residues and weeds were rated in terms of percentage of sampled plants surrounded by residues or weeds as follows: $0 \%=$ 


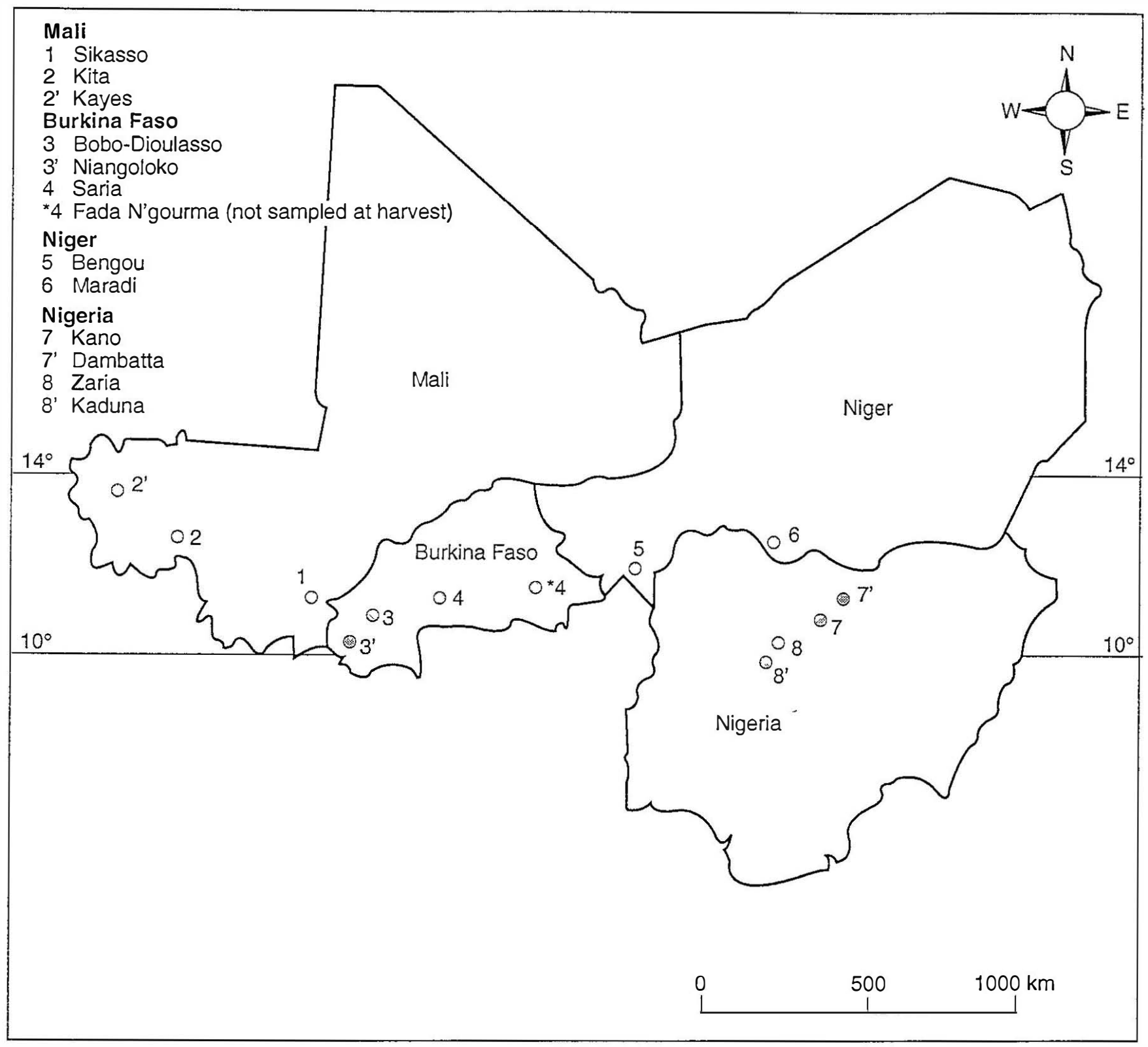

Fig. 1. Localities in four countries in West Africa surveyed for termites on groundnut

0 (none); $1-5 \%=1$ (very low); $6-15 \%=2$ (low); $16-25 \%=3$ (Fairly high); 26-35\% = 4 (high); 36$45 \%=5$ (very high). Farms overgrown with weeds were not sampled.

The influence of rainfall on soil pest abundance was evaluated using mean annual rainfall values derived from an established rainfall map for the sub-region (l'Hôte and Mahé, 1996) compiled with data collected between 1951-1989.

\section{Statistical analysis}

The levels of weed and of plant residues were grouped and rated. These were subjected to simple regression analyses in relation to termite frequency of occurrence in the soils. Simple and multiple regression analyses were computed for other factors associated with termite abundance.
Data on percentage of plants attacked by termite were transformed for the regression analysis. Ttest analyses were also computed for soil pest population densities at 25-45 DAP and at harvest using transformed data. All data were analysed using the SAS statistical analysis program (SAS Inc., 1985).

\section{RESUlts}

Diversity of soil-borne arthropods and in relation to soil textures

Several soil arthropods belonging to 3 families were identified across the groundnut belts (Table 1) out of which the termites (Isoptera: Termitidae), whitegrubs (Coleoptera: Scarabaeidae) and millipedes (Diplopoda: Odontopygidae) were 
Table 1. Incidence and diversity of soil pests in soil of groundnut farms in Mali, Burkina-Faso, Niger and Nigeria

\begin{tabular}{|c|c|c|}
\hline $\begin{array}{l}\text { Soil pests observed } \\
\text { on groundnut }\end{array}$ & Localities & $\begin{array}{l}\text { Soil texture of } \\
\text { infested farms }\end{array}$ \\
\hline $\begin{array}{l}\text { Isoptera } \\
\text { Microtermes lepidus Sjostedt } \\
\text { M. parvulus Sjostedt } \\
\text { Microtermes sp. } \\
\text { Odontotermes smeathmani Sjostedt } \\
\text { Odontotermes sp. } \\
\text { Pseucanthotermes militaris Hagen } \\
\text { Pericapritermes sp. } \\
\text { Macrotermes subhyalinus Rambur } \\
\text { Trinervitermes sp. }\end{array}$ & $\begin{array}{r}1,2,3,4,5,6,7 \\
1,4,7,8 \\
6 \\
8 \\
1,6 \\
1 \\
1 \\
1,2,7 \\
1\end{array}$ & $\begin{array}{r}\text { S, LS, SL, SCL } \\
\text { S, LS, SL, SCL } \\
\text { S, LS, SL, SCL } \\
\text { LS, SL, SCL } \\
\text { LS, SL, SCL } \\
\text { LS } \\
\text { LS } \\
\text { LS, SL, SCL } \\
\text { LS }\end{array}$ \\
\hline $\begin{array}{l}\text { Coleoptera }^{+} \\
\text {Scarabaeidae } \\
\text { Schyzonicha africana Lap. } \\
\text { Heteronychus sp. (larva and adult) } \\
\text { Anomala sp. } \\
\text { Trochalus sp. }\end{array}$ & $\begin{array}{r}1,2,5,6,7,8 \\
6 \\
2 \\
3\end{array}$ & $\begin{array}{r}\text { S, LS, SL } \\
\text { S, LS, SL } \\
\text { LS } \\
\text { S }\end{array}$ \\
\hline $\begin{array}{l}\text { Elateridae } \\
\text { Cardiophorus sp. } \\
\text { Unidentified larva } \\
\text { Zophosis sp. (adult) } \\
\text { Unidentified larva }\end{array}$ & $\begin{array}{r}1,6 \\
1,5,6,7,8\end{array}$ & $\begin{array}{r}\text { LS, LS } \\
\text { S, LS, SL. SLC }\end{array}$ \\
\hline $\begin{array}{l}\text { Carabidae } \\
\text { Clivina sp. (adult) }\end{array}$ & 7 & $S$ \\
\hline $\begin{array}{l}\text { Curculionidae } \\
\text { Anaemerus sp. }\end{array}$ & 6 & $S$ \\
\hline $\begin{array}{l}\text { Myriapoda } \\
\text { Odontopygidae } \\
\text { Peridontopyge spinossima Silvestri } \\
\text { Peridontopyge sp. } 1 \\
\text { Peridontopyge sp. } 2\end{array}$ & $\begin{array}{r}1,2,3,7,8 \\
1,3,4,6,8 \\
3,4,6\end{array}$ & $\begin{array}{l}\text { S, LS, SL, SCL } \\
\text { S, LS, SL, SCL } \\
\text { S, LS, SL, SCL }\end{array}$ \\
\hline
\end{tabular}

classified as being economically important. Some species were limited to only a few of the localities while others were widely distributed across the region. The latter category included termite species such as Microtermes lepidus Sjöstedt, Microtermes paroulus Sjöstedt, and to a lesser extent Odontotermes spp. and Macrotermes subhyalinus Rambur. Widely distributed coleopteran and myriapod species were Schyzonycha africana Lap. and Peridontopyge spp. All millipede species belonged to the same family, although some could not be named. The incidence of wireworms (Coleoptera: Elateridae) and false wireworms (Coleoptera: Tenebrionidae) was almost negligible.

Soils in groundnut farms were predominantly of sandy (52\%) or loamy sand (32\%) in texture. Sandy loam and sandy clay loam soils were only observed in $16 \%$ of the farms. The predominant Microtermes spp. were identified in all soil types in the localities studied (Table 1).

In $85 \%$ of the farms infested by whitegrubs, the soils were of sandy and loamy sand texture. Very few grubs were observed in soils with sandy clay loam texture. There was a negative correlation $\left(r^{2}=0.43 ; P<0.03 ; n=10\right)$ between the percentage of clay in a farm $\left(x_{1}\right)$ and the occurrence of whitegrubs in it $\left(\mathrm{y}_{1}\right)$. The latter was predicted by the model $\mathrm{y}_{1}=5.401-0.218 \mathrm{x}_{1}$. However, correlation analysis between whitegrub population density and the percentage of clay was low and nonsignificant. Neither millipede population density nor its frequency of occurrence bore any relationship with the soil texture of the surveyed farms. Organic carbon content of sampled fields, which ranged between 0.10 and $0.88 \%$, did not 
Table 2. Population densities of termites in localities of Mali, Burkina-Faso, Niger and Nigeria '

\begin{tabular}{|c|c|c|c|c|c|c|c|}
\hline \multirow[b]{3}{*}{ Localities } & \multicolumn{6}{|c|}{ Mean population density of soil pests (no. $/ \mathrm{m}^{2}$ ) } & \multirow{3}{*}{$\begin{array}{l}\text { Annual } \\
\text { rainfall } \\
(\mathrm{mm})\end{array}$} \\
\hline & \multicolumn{2}{|c|}{ Termites } & \multicolumn{2}{|c|}{ Whitegrubs } & \multicolumn{2}{|c|}{ Millipedes } & \\
\hline & $25-45 \mathrm{DAP}$ & Harvest & 25-45 DAP & Harvest & 25-45 DAP & Harvest & \\
\hline Sikasso+ & $183 \pm 45^{a}$ & $170 \pm 35^{b}$ & $0.6 \pm 0.3$ & $0.6 \pm 0.2$ & $0.4 \pm 0.1$ & $2.2 \pm 0.5$ & 1100 \\
\hline Kita/Kayes+ & $75 \pm 13^{c}$ & $2.1 \pm 0.4$ & $7.3 \pm 2.8$ & 0 & $7.2 \pm 2.1$ & 0 & 900 \\
\hline $\begin{array}{l}\text { Bobo-Dioulasso/ } \\
\text { Niangoloko+ }\end{array}$ & $15 \pm 6$ & $15 \pm 6$ & $2.1 \pm 0.5$ & $1.6 \pm 0.8$ & $3.9 \pm 1$ & $2.9 \pm 1.2$ & 1100 \\
\hline Saria++ & 0 & $49 \pm 4.7$ & 0 & 0 & $2.6 \pm 0.4$ & $0.2 \pm 0.1$ & 700 \\
\hline Bengou++ & 0 & $146 \pm 34$ & $1.6 \pm 0.2$ & $0.8 \pm 0.1$ & $7.6 \pm 1.4$ & $0.6 \pm 0.1$ & 800 \\
\hline Maradit & $123 \pm 39$ & $18 \pm 5$ & $2.5 \pm 0.6$ & $1.8 \pm 0.4$ & $0.9 \pm 0.3$ & $0.7 \pm 0.3$ & 600 \\
\hline Kano/Dambatta+ & $4 \pm 1.2$ & $5 \pm 2$ & $0.6 \pm 0.2$ & $0.2 \pm 0.1$ & $2.4 \pm 0.7$ & $0.6 \pm 0.2$ & 800 \\
\hline Zaria/Kadunat & $189 \pm 90^{d}$ & $4 \pm 1.2$ & $5.2 \pm 1.7$ & 0 & $10.3 \pm 2.8$ & $0.8 \pm 0.3$ & 1100 \\
\hline
\end{tabular}

+10 farms sampled; ++ 5 farms sampled.

\#Unless otherwise stated termite population density refers to Microtermes spp.

a Odontotermes constituted $2 \%$ of population; ${ }^{b}$ Macrotermes constituted $9.6 \%$ of population;

${ }^{c}$ Odontotermes constituted $15 \%$ of population; ${ }^{\mathrm{d}}$ Macrotermes constituted $16 \%$ of population.

play any significant role in soil arthropod distribution. The $\mathrm{pH}$ of the classified soils varied between 4.9 and 7.4 , with $87 \%$ of the soil samples being acidic (mean $\mathrm{pH}$ of 5.9). No relationship of
$\mathrm{pH}$ with the frequency of occurrence or population density of the observed soil arthropods was found.

Table 3. Incidence of soil pests, associated damage and yield losses of groundnuts in localities of Mali, BurkinaFaso, Niger and Nigeria

\begin{tabular}{|c|c|c|c|c|c|c|c|c|c|c|}
\hline & \multicolumn{3}{|c|}{$\begin{array}{l}\text { Number of farms } \\
\text { infested by soil pests } \\
\text { (observed from soil } \\
\text { and plant samples) }\end{array}$} & \multicolumn{3}{|c|}{$\begin{array}{l}\text { Number of farms with } \\
\text { infested soils and } \\
\text { mean } \% \text { attacked } \\
\text { plants at } 25-45 \text { DAP }\end{array}$} & \multicolumn{3}{|c|}{$\begin{array}{c}\text { Number of farms with } \\
\text { infested soils and mean } \\
\% \text { attacked plants at } \\
\text { plant maturity }\end{array}$} & \multirow[t]{2}{*}{$\begin{array}{l}\text { Mean }(\%) \\
\text { yield loss }\end{array}$} \\
\hline & $\mathrm{T}$ & $\mathrm{W}$ & $\mathrm{M}$ & $\mathrm{T}$ & $W$ & $\mathrm{M}$ & $\mathrm{T}$ & $W$ & $\mathrm{M}$ & \\
\hline Sikasso + & 8 & 2 & 6 & $\begin{array}{c}4 \\
(10)^{\#}\end{array}$ & $\begin{array}{c}1 \\
(0.5)\end{array}$ & $\begin{array}{c}0 \\
(0)\end{array}$ & $\begin{array}{c}8 \\
(12.5)\end{array}$ & $\begin{array}{c}2 \\
(2)\end{array}$ & $\begin{array}{c}6 \\
(13)\end{array}$ & 13.80 \\
\hline Kita/Kayes+ & 7 & 5 & 7 & $\begin{array}{c}5 \\
(3.1)\end{array}$ & $\begin{array}{c}5 \\
(6.8)\end{array}$ & $\begin{array}{c}7 \\
(4.2)\end{array}$ & $\begin{array}{c}2 \\
(39.4)\end{array}$ & $\begin{array}{c}0 \\
(0)\end{array}$ & $\begin{array}{c}0 \\
(0)\end{array}$ & 30.40 \\
\hline $\begin{array}{c}\text { Bobo-Dioulasso/ } \\
\text { Niangoloko+ }\end{array}$ & 6 & 2 & 4 & $\begin{array}{c}3 \\
(1.3)\end{array}$ & $\begin{array}{c}1 \\
(1.2)\end{array}$ & $\begin{array}{c}3 \\
(2.5)\end{array}$ & $\begin{array}{c}3 \\
(12)\end{array}$ & $\begin{array}{c}2 \\
(0)\end{array}$ & $\begin{array}{c}1 \\
(06)\end{array}$ & 9.6 \\
\hline Saria++ & 3 & 0 & 1 & $\begin{array}{c}2 \\
(0)\end{array}$ & $\begin{array}{c}0 \\
(0)\end{array}$ & $\begin{array}{c}1 \\
(1.5)\end{array}$ & $\begin{array}{c}2 \\
(13)\end{array}$ & $\begin{array}{c}0 \\
(0)\end{array}$ & $\begin{array}{c}0 \\
(0)\end{array}$ & 18.50 \\
\hline Bengou++ & 3 & 2 & 3 & $\begin{array}{c}0 \\
(0)\end{array}$ & $\begin{array}{c}2 \\
(0)\end{array}$ & $\begin{array}{c}3 \\
(9.3)\end{array}$ & $\begin{array}{c}3 \\
(11)\end{array}$ & $\begin{array}{c}1 \\
(11)\end{array}$ & $\begin{array}{c}1 \\
(1.5)\end{array}$ & 22.80 \\
\hline Maradi+ & 8 & 7 & 3 & $\begin{array}{c}6 \\
(2.7)\end{array}$ & $\begin{array}{l}3 \\
(1)\end{array}$ & $\begin{array}{c}3 \\
(1.5)\end{array}$ & $\begin{array}{c}3 \\
(14)\end{array}$ & $\begin{array}{c}5 \\
(0.5)\end{array}$ & $\begin{array}{c}2 \\
(0.4)\end{array}$ & 21.10 \\
\hline $\begin{array}{l}\text { Kano/ } \\
\text { Dambatta+ }\end{array}$ & 4 & 2 & 2 & $\begin{array}{l}2 \\
(6)\end{array}$ & $\begin{array}{c}2 \\
(0)\end{array}$ & $\begin{array}{c}1 \\
(2.6)\end{array}$ & $\begin{array}{c}2 \\
(20.3)\end{array}$ & $\begin{array}{c}1 \\
(0.6)\end{array}$ & $\begin{array}{c}1 \\
(0.4)\end{array}$ & 16.90 \\
\hline $\begin{array}{l}\text { Zaria / } \\
\text { Kaduna+ }\end{array}$ & 5 & 4 & 7 & $\begin{array}{c}3 \\
(1.9)\end{array}$ & $\begin{array}{c}4 \\
(1.4)\end{array}$ & $\begin{array}{c}5 \\
(3.7)\end{array}$ & $\begin{array}{c}5 \\
(6.4) \\
\end{array}$ & $\begin{array}{c}2 \\
(1.3)\end{array}$ & $\begin{array}{c}2 \\
(9) \\
\end{array}$ & 10.0 \\
\hline
\end{tabular}

+10 farms sampled; ++5 farms sampled.

$\mathrm{T}=$ termites, $\mathrm{W}=$ whitegrubs, $\mathrm{M}=$ millipedes.

\#Mean \% attacked plants. 


\section{Soil arthropod distribution and annual rainfall}

In all localities, at least $40 \%$ of the sampled farms were infested with termites, while at least 30 and $40 \%$ respectively were infested with whitegrubs and millipedes. At crop maturity, termites, whitegrubs and millipedes were present in soil samples in less than $28 \%$ of the farms. The population density of termites observed in soil

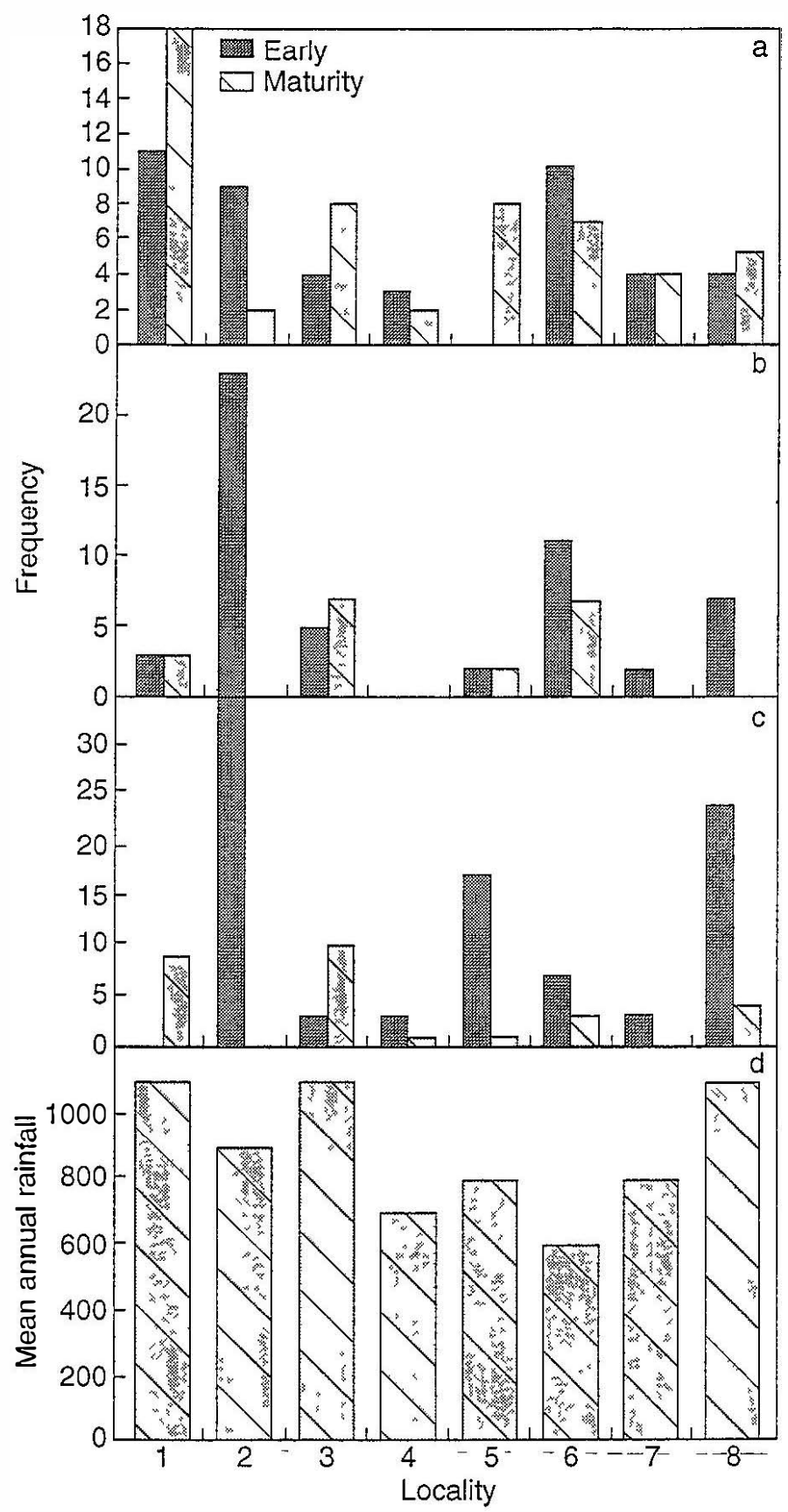

Fig. 2. Relationships between mean annual rainfall and frequencies of occurrence of (a) termites, (b) whitegrubs, and (c) millipedes in groundnut farms in some West African localities: 1, Sikasso (Mali); 2, Kita / Kayes (Mali);3, Bobo-Dioulasso/Niangoloko (BurkinaFaso); 4, Saria (Burkina-Faso); 5, Bengou (Niger); 6 , Maradi (Niger); 7, Kano/Dambatta (Nigeria); 8, Kaduna/Zaria (Nigeria) samples decreased towards the end of the season (Table 2) except in Saria and Bengou areas where the early-maturing varieties planted there matured before the end of the rainy season. Similarly, whitegrub and millipede population densities decreased at plant maturity except in Sikasso and Saria areas where early-maturing varieties were cultivated. Frequencies of occurrence of soil arthropods in soil samples generally decreased at groundnut maturity except in Sikasso and Bobo Dioulasso (Table 2; Figs. 2a, $2 \mathrm{~b}$ and $2 \mathrm{c}$ ).

During the later part of the cropping season, localities with $\leq 900 \mathrm{~mm}$ annual rainfall had more termites on plants than in the soils (Tables 2 and 3). In Maradi, with $600 \mathrm{~mm}$ mean annual rainfall for example, the mean population densities of termites in soils at early and mature stages of

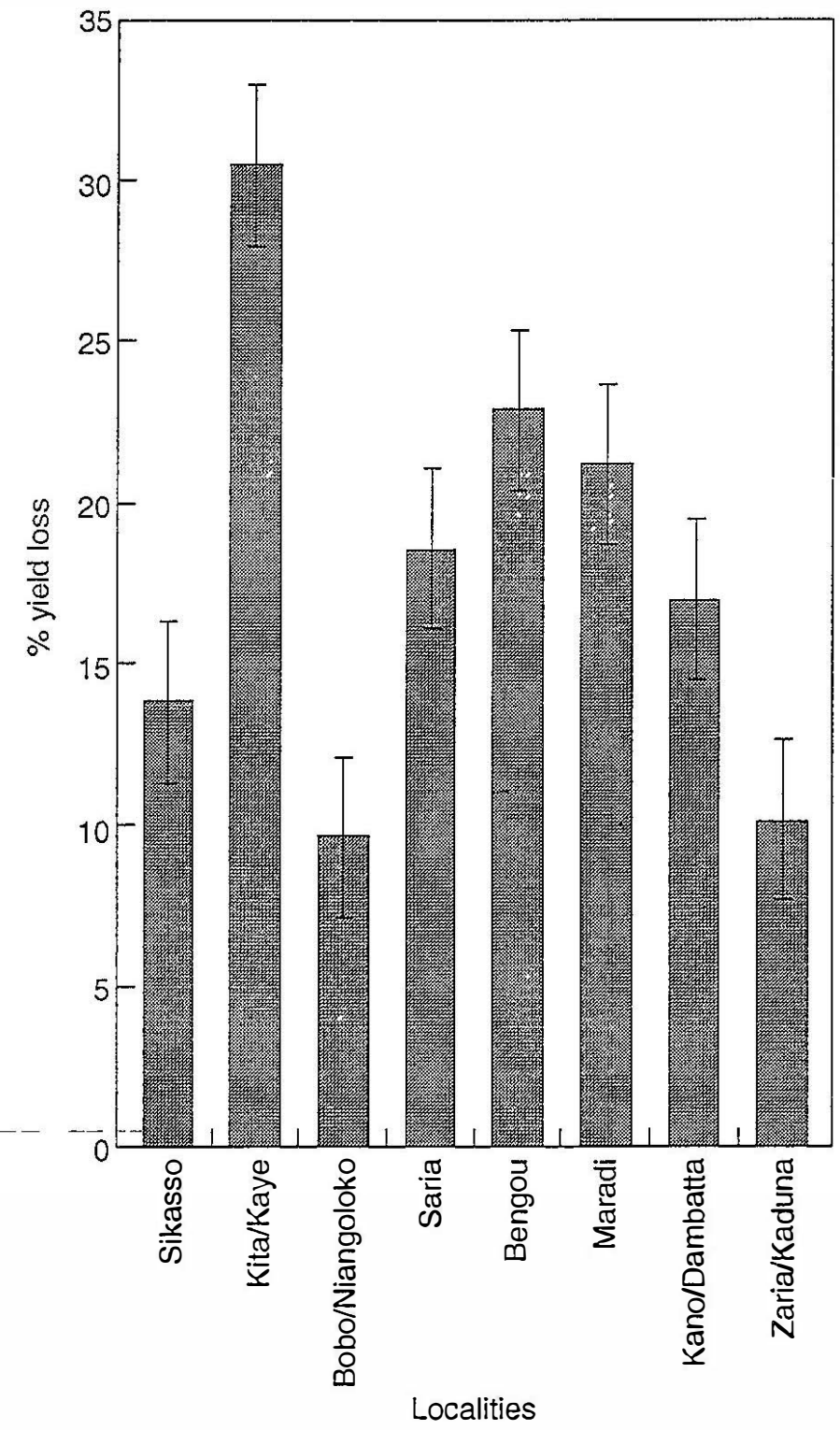

Fig. 3. Groundnut yield losses due to soil pest damage in West Africa 
groundnut were $123 / \mathrm{m}^{2}$ and $18 / \mathrm{m}^{2}$ respectively, while the percentage of attacked plants increased from $2.7 \%$ at the early stage of the crop to $14 \%$ at harvest. However, regression coefficients of the population density and frequency of occurrence of termites, whitegrubs, and millipedes against the annual rainfall levels were not significantly different $(P<0.05)$. T-test analysis of the mean population densities of the soil pests in the soil samples at 25-45 DAP and at harvest showed no significant difference in the termite population densities. There were significant differences between 25-45 DAP and harvest population densities of whitegrubs $(\mathrm{t}=2.12 ; \mathrm{n}=8 ; \mathrm{P}<0.05)$ and millipedes $(\mathrm{t}=2.72 ; \mathrm{n}=8 ; \mathrm{P}<0.01)$.

\section{Influence of crop residue and weed levels on termite spread}

The distribution of Microtermes species in groundnut farms was influenced by residues of previous cereal crops such as sorghum, maize and millet. At 25-45 DAP, 68\% of the farms in which the level of cereal residues were rated as 'high' and $100 \%$ of those in which residues were rated as 'very high' were infested with Microtermes species. There was a positive correlation $\left(r^{2}=\right.$ $0.227 ; P<0.01 ; \mathrm{n}=28$ ) between the frequency of termite occurrence $\left(\mathrm{y}_{2}\right)$ and the level of residues $\left(x_{2}\right)$ as predicted by the model $y_{2}=0.9448+0.847 x_{2}$. However, the correlation between population densities and levels of residue was very low $(r=$ 0.38 ). No relationship was observed between the frequency of termite occurrence or its population density and the levels of weeds.

\section{Groundnut damage by soil pests}

Termite damage was most severe at plant maturity (Table 3). The varieties attacked-mostly local varieties-varied considerably within a locality and across the sub-region. The damaging termites in order of decreasing importance were Microtermes, Odontotermes, and Macrotermes species. The percentage of plants attacked had a Tow positive correlation ( $r=0.35 ;-P-<-0.05 ; n=-25)$ with the Microtermes population density in soil samples at 25-45 DAP. At plant maturity, no such correlation was observed. The mean percentage of attacked plants was up to $39.4 \%$ in the Kita localities where $90 \%$ plant attack was observed in a farm.

Termite were found in various species of $A$ cacia and the Shea tree, Butyrospermumn parkii (G. Don)
Kotschy. The termites Nasutitermes and Coptotermes spp. which occurred on these trees were not associated with groundnut damage.

Active termite mounds were rarely observed in the sampled cultivated farms. Only 1 or 2 mounds per farm were seen on 2 farms at Kita and 3 at Sikasso. Macroternes subhyalinus Rambur colonies damaged groundnuts located at radii not exceeding $6 \mathrm{~m}$ from their mounds.

Eleven percent of the sampled plants were attacked by whitegrubs. The percentages of plants attacked at 25-45 DAP $\left(\mathrm{y}_{3}\right)$ and at plant maturity $\left(y_{1}\right)$ were positively correlated with the population densities of whitegrub $\left(x_{3}\right.$ and $\left.x_{4}\right)$ in soils at the two respective periods $\left[\left(r^{2}=0.43 ; n=18 \mathrm{P}<0.01\right)\right.$ and $\left.\left(r^{2}=0.72 ; n=13 ; P<0.01 ;\right)\right]$, and were predicted by the models $\mathrm{y}_{3}=0.141+0.745 \mathrm{x}_{3}$ and $\mathrm{y}_{4}=0.037+$ $0.71 x_{4}$. The percentages of attacked plants were also positively correlated with the frequencies of whitegrub occurrence at 25-45 DAP $\left(r^{2}=0.35 ; P<\right.$ $0.05 ; \mathrm{n}=18)$ and at maturity $\left(r^{2}=0.59 ; P<0.01 ; n\right.$ $=13$ ). Multiple regression analysis of the percentage of plants attacked by whitegrub at 25$45 \mathrm{DAP}$ versus whitegrub population density and mean annual rainfall showed that the increase of $r^{2}=0.43$ (for the population density alone) to $R^{2}=$ 0.46 (population density and rainfall) was not significant $(P>0.05)$.

There was a decrease in millipede attack at plant maturity in all localities, with the exception of Sikasso area where groundmuts matured well before the end of the rains (Table 3 ). The maximum mean plants attacked by millipedes per farm was 9.3\% at plant maturity.

Millipede population densities and their frequencies of occurrence were positively correlated with the percentages of attacked plants both at 25-45 DAP $\left(r^{2}=46\right.$ and $r^{2}=42$ respectively; $P<0.05 ; \mathrm{n}=20)$ and at plant maturity $\left(r^{2}=0.81\right.$ and $r^{2}=0.78$ respectively; $P<0.001 ; \mathrm{n}=13$ ). Millipede population densities $x_{5}$ and $x_{6}$ predicted attacks $y_{5}$ and $y_{6}$ as follows: $y_{5}=1.82+0.37 x x$ and $\mathrm{y}_{6}=1.051+0.36 \mathrm{x}_{5}$ at 25-45 DAP and at maturity respectively. In Fada $N^{\prime}$ gourma area the mean percentage of attacked plants at $25 \mathrm{DAP}$ by the-seil-pests-was $15 \%$. This area was not visited at harvest, hence, no data on damage at maturity was obtained.

\section{Estimation of yield losses}

Damage of pods at plant maturity was predominantly caused by termites. Pod damage by whitegrubs and millipedes was low and 
accounted for less than $5 \%$ of the damage where observed. Summing up the mean percentages of plants attacked in each locality by the three major groups of soil pests (Table 3), a maximum of 39\% of attacked plants was observed. However, it became obvious during yield loss assessment that some soft pods damaged by millipedes were decaying, indicating that pods attacked earlier could have decayed long before harvest. Losses such as these did not allow for the computation of all yield losses.

Yield losses of groundnut kernels from plants attacked by termites, the major damage-causing group, ranged between $21.1 \%$ and $38 \%$. Mean percentage yield losses exceeding 20\% (Table 3) were recorded in farms in the localities of Kita/ Kayes (Mali), Bengou and Maradi in Niger (Fig. $3)$. A significant positive correlation $\left(r^{2}=0.731 ; P\right.$ $<0.001 ; n=25$ ) existed between the percentage of sampled plants attacked by termites $\left(x_{7}\right)$ and the yield loss $\left(\mathrm{y}_{7}\right)$, and the latter was predicted by the model $y_{7}=9.907+0.698 x_{7}$

\section{Discussion}

Termites were the major soil-borne arthropods in the surveyed areas, followed by whitegrubs and millipedes. Sandy and loamy sand soils favourable for groundnut production were preferred over the other types by three major groups of soil arthropods. Whereas termites and millipedes were present in all soil types, whitegrubs on the other hand were rarely observed in soils with a high proportion of clay as shown by regression analysis. This was probably due to the compact nature of clayey soils which may deter easy penetration by the relatively soft bodies of whitegrubs.

During the later part of the cropping season, localities with $900 \mathrm{~mm}$ annual rainfall or less had more termites on groundnut plants than in the surrounding soils, possibly because termites left the bare soils, to obtain food and moisture directly from the plants. This may explain the high termite damage on plants -usually_associated_with_dry periods and regions. Johnson et al. (1981) similarly reported that termite invasion of taproots was particularly severe with the onset of the dry season. In high rainfall areas, a period of drought may also result in serious termite damage (such erratic rainfall patterns are characteristic of tropical West Africa). In the present study, this may have contributed to the non-significant correlation between termite attack and the mean annual rainfall. However, in areas where annual rainfall was $\leq 900 \mathrm{~mm}$, there was an earlier onset of dry season and associated

reflected by the high yield losses due to the termites.

The low occurrence of whitegrubs observed at plant maturity may mean that the dry soil topsoils (up to $30 \mathrm{~cm}$ ) at the end of the cropping season could not support their presence in soils and the grubs may have migrated to deeper; more moist sub-soils. Wightman and Wightman (1994) reported the occurrence of high whitegrub densities in areas of high annual rainfall ( $>1000$ $\mathrm{mm}$ per year). Demange (1975) reported the incidence of vertical migration associated with declining levels of moisture in various soil strata and reported 30-60 $\mathrm{cm}$ depths as being most commonly occupied by millipedes at the beginning of the dry season. Rossion (1976) also noted among other factors that millipedes aestivate in microhabitats in which sufficient moisture is available, such as cavities of abandoned termite mounds, and in roots of trees and shrubs.

Abundance of previous-season cereal residues contributed to the high frequency of occurrence of Microtermes spp. in the farms, since the identified species were mostly plant litter feeders which thrive on these residues. Maize, for example, has been identified as one of the crops preferred by Microtermes (Wood et al., 1980; Umeh and Ivbijaro, 1997). A higher positive relationship was obtained when correlating termite frequencies of occurrence instead of population densities with residue levels. This may be due to termite aggregation or their foraging behaviour of taking food away from the sources (sampled areas). Therefore the number of points with termite presence was frequently observed in relation with residues distribution in fields than their population. The removal or partial burning of the residues is likely to reduce population carryover. The contribution of crop residues to termite damage has been documented by Sands, (1977), Srivastava and-Butani (1987), Umeh (1995), and Umeh and Ivbijaro (1997).

A very low positive correlation existed between termite population density in the soil and the percentage of attacked plants $25-45$ DAP. This correlation disappeared at plant maturity. This was attributed to the concentration of termites in mature groundnut pods and roots rather than in the dry soils. 
Despite lower attack of groundnut by whitegrubs compared to termites, strong positive relationships were calculated between the population densities and frequencies of occurrence of whitegrubs and the percentage of attacked plants. The feeding of whitegrubs on roots close to their temporary nests increases the chances of encountering the grubs in soil samples and the corresponding damaged plants. Termites, on the other hand, may forage for food far from their nests. The observed trend of millipede attack was similar to that of Demange (1975), where it was reported that food materials with less than $40 \%$ moisture are not preferred by millipedes; hardened pods with less moisture were less attacked than germinating seeds or developing pods. The significantly high positive relationships between millipede populations and the percentage of attacked plants indicated that the millipedes were likely to be present in the vicinity of the plants they damaged and thus were positively scored (in soil samples) simultaneously with the plants they attacked. This might be connected with the more favourable micro-climate existing in the vicinity of the plants than in bare soils elsewhere in the farm.

Termites of the genera Nasutitermes and Coptotermes identified on trees were not associated with groundnut damage and therefore may not have been a cause for concern for groundnut farmers. However, they are known to pose considerable problems to the production of economic trees (Harris, 1971; Lee and Wood, 1971), and therefore should be controlled. Damage by the epigeous Macrotermes subhyalinus was localised within a few metres of their mounds, and can thus be controlled physically by mound destruction and removal of the queen termites (Darlington, 1985).

Groundnut damage by soil pests and the pest species involved varied from one locality to another. Areas of Kita/Kayes (Mali), and Bengou and Maradi (Niger) recorded higher attack by termites, whitegrubs and millipedes than any other area. However, the results showed that pod yield losses were mostly caused by termites.

The results establishes the relative importance of termites, whitegrubs, and millipedes as major biotic constraints in the groundnut belts of Mali, Burkina-Faso, Niger and Nigeria. Although the importance of each group varied from one location to another, pod yield losses during harvest were predominantly caused by termites in all locations. Cereal residues usually left on the soil by the farmers contributed significantly to termite spread within such farms. Increased termite damage may also have been influenced by early onset of the dry season associated with low annual rainfall areas. Comparatively lower percentages of attacked plants were observed in the high rainfall areas of Sikasso, Bobo-Dioulasso/Niangoloko and Zaria/Kaduna, although these were not significantly different. Soils with low clay contents were observed to be most preferred by whitegrubs compared to termites and millipedes, which colonised all soils types. The present study also showed that all the three major groups of pests should be taken into consideration in designing control measures for groundnut soil pests.

Acknowledgement-We thank the National Agricultural Research Systems (NARS) of the various countries visited for logistical support. We are also grateful to Drs K. F. Nwanze, A. Ratnadass, J. A. Wightman and O. Ajayi for their useful suggestions, and to Drs O. Youm and B. Ntare for their useful comments on the manuscript. Submitted as Journal Article No. 2103 by ICRISAT.

\section{REFERENCES}

Brady N. C. (1984) The Nature and Properties of Soils. M/S Eurosia Publishing House (P) Ltd. India 750 pp.

Darlington J. P. E. C. (1985) Multiple primary reproductives in the termite Macrotermes michaelseni (Sjostedt.), pp. 187-200. In Caste Differentiation in Social Insects (Edited by J. A. L. Watson, B. M. OkotKotber and C. Noirot). Pergamon Press, Oxford.

Demange J. M. (1975) Les myriapodes diplopodes, nuisibles à l'arachide au Sénégal. Oléagineux 30, 19-24.

Dicko I. O. and Lynch R. E. (1995) Effectiveness of soilapplied insecticide against foliage and pod-feeding arthropod pests in Burkina Faso. International Arachis Newsletter 15, 60-62.

Harris W. V. (1971) Termites: Their Recognition and Control. Longman London. $186 \mathrm{pp}$.

Johnson R. A. and Gumel M. H. (1981) Termite damage and crop loss studies in Nigeria-The incidence of termite-scarified groundnut pods and resulting kernel-contamination in field and market samples. Trop. Pest Manage. 27, 343-350.

Johnson R.-A., Lamb R. W. and Wood T. G. (1981) Termite damage and crop loss studies in NigeriaA survey of damage to groundnuts. Trop. Pest Manage. 27, 325-342.

Lee K. E. and Wood T. G. (1971) Termite and Soils. Academic Press, London and New York. 251 pp.

L'Hote Y. and Mahe G. (1996) Afrique de l'ouest et centrale: Précipitations moyennes annuelles. Département eaux 
continentales, ORSTOM, Montpellier Cedex, France.

Lynch R. E, Ouedrogo A. P. and Dicko I. (1986) Insect damage to groundnut in semi-arid tropical Africa, pp. 175-183. In Agrometeorology of Groundnut. Proceedings of an International Symposium, 21-26 Aug 1985, ICRISAT Sahelian Centre, Niamey, Niger. ICRISAT, Patancheru, A. P. 502 324, India.

Masses H. (1981) Lutte contre les iules (Diplopodes, Spirostreptoidea) en culture arachidière au Sénégal. Oléngineux 36, 555-562.

Mercer P. C. (1978) Pests and diseases of groundnuts in Malawi. II. Disorders of pods, kernels and seedlings. Oléagineux 33, 119-122.

Rossion J. (1976) Les iules, déprédateurs de l'arachide au Sénégal. Résultats récents obtenus en matière de lutte chimique. Oléngineulx 31, 327-333.

Sands W. A. (1977) The role of termites in tropical agriculture. Outlook on Agriculture 9, 136-143.

SAS Institute (1985) SAS User's Guide: Statistics. 5th Ed. SAS Inst., Cary, North Carolina.

Srivastava K. P. and Butani D. K. (1987) Insect pests of tea in India and their control. Pesticide 21, 16-21.
Umeh V. C. (1995) Effect of termites in traditional intercrops involving citrus and pepper in parts of south-western Nigeria. Paper presented at the 10th Conference of the Horticultural Society of Nigeria (HORTSON), Kwara State Agricultural Development Program, Ilorin, Nigeria, 12-15 March 1995. 9 pp.

Umeh V. C. and Ivbijaro M. F. (1997) Termite abundance and damage in traditional maize-cassava intercrops in southwestern Nigeria. Insect Sci. Applic. 17,315321.

Waliyar F., Ba A., Hamma H., Bonkoungou S. and Bosc J. P. (1994) Sources of resistance to Aspergillus flavus and aflatoxin contamination in groundnut genotypes in West Africa. Plant Disease 78, 704-708.

Wightman J. A. and Wightman A. S. (1994) An insect, agronomic and sociological survey of groundnut fields in southern Africa. Agric. Ecosyst. Environ. 51, 311-331.

Wood T. G., Johnson R. A. and Ohiagu C. E. (1980) Termite damage and crop loss A review of termite damage to maize and estimation of damage, loss in yield and Microtermes abundance at Mokwa. Trop. Pest Manage. 26, 241-253. 